\title{
Fruit Exploration Supported by the National Plant Germplasm System, 1980 to 2004
}

\author{
Philip L. Forsline ${ }^{1}$ \\ USDA, ARS, Plant Genetic Resources Unit, Cornell University, 630 W. North Street, Geneva, NY 14456-0462 \\ Kim E. Hummer ${ }^{2}$ \\ USDA ARS National Clonal Germplasm Repository, 33447 Peoria Road, Corvallis, OR 97333-2521
}

Additional index words. Plant genetic resources, plant exchange, clonal repository

\begin{abstract}
The National Plant Germplasm System (NPGS) of the U.S. Department of Agriculture (UDSA), Agricultural Research Service (ARS), has greatly expanded since 1980. Foremost in this expansion was the addition of seven repositories for clonally propagated fruit and specialty crops. Many collections at state agricultural experiment station sites were in jeopardy as breeders retired. These collections can now be preserved by the NPGS. The NPGS has provided funding for plant exploration and exchange. From 1980 to 2004, 37 exploration/exchange proposals for fruit crops were funded, and over 3000 accessions introduced as a result. Crop Germplasm Committees (CGCs), established for each commodity have prepared genetic vulnerability statements and prioritized collection activities. The USDA ARS, National Germplasm Resources Laboratory (NGRL), facilitates international relationships, and the USDA Animal and Plant Health Inspection Service (APHIS), National Plant Germplasm Quarantine Center (NPGQC), tests and makes pathogen-tested germplasm available. As a result of the Convention on Biological Diversity (1993) and the International Treaty on Plant Genetic Resource for Food and Agriculture (2004), the USDA now pursues germplasm collection through the establishment of bilateral agreements of mutual benefit.
\end{abstract}

\section{INTRODUCTION}

In the $1970 \mathrm{~s}$, fruit scientists recognized the need to conserve fruit and nut genetic resources in the UDSA, ARS, NPGS (Brooks and Barton, 1977). Before this, many fruit germplasm collections at state agricultural experiment stations had been eliminated when breeders retired and programs were redirected.

From that effort came funding from the Unites States Congress, through Farm Bills for the Department of Agriculture. Seven federally funded fruit and specialty crop genebanks came into existence. As the repositories became established, the funding available for plant exploration and exchange was also increased. A mechanism for prioritizing proposals for collections of each commodity was established. Crop Germplasm Committees (CGCs), national, and sometimes international, groups of experts for particular crops were formed. Crop Curators and site managers were assigned to ex officio appointments on these committees. These committees prepare and regularly review genetic vulnerability statements, identify gaps in the United States national plant collections, and recommend areas for germplasm collection.

Between 1985 and 1995, the late Dr. Calvin Sperling, Plant Explorer for the USDA ARS, National Germplasm Resources Laboratory (NGRL), Beltsville, Md., was influential in working with the CGCs. He facilitated the process of prioritization and establishment of international relationships in the era before international treaties for exchange of plant genetic resources became

\footnotetext{
The cost of publishing this paper was defrayed in part by the payment of page charges. Under postal regulations, this paper therefore must be hereby marked advertisement solely to indicate this fact.

${ }^{1}$ Research Leader/Curator.

${ }^{2}$ Research Leader/Curator;

e-mail khummer@ars-grin.gov
}

common. The NGRL staff continues this work. In addition, the NPGQC, Beltsville, Md., now run by APHIS, has also been a critical link in moving exotic, foreign, vegetatively propagated germplasm in the "prohibited" category into NPGS collections to be available to researchers around the world. Once plant material is released through quarantine, it is distributed to the appropriate genebank and inventory is tracked on the Germplasm Resources information Network (GRIN), which includes complete origin documentation including detailed passport information, latitude and longitude, and herbarium specimens for wild species.

From 1980 to 2004, 37 exploration/ exchange proposals were funded for fruit crops by the USDA (Table 1). These fruit explorations will be summarized by crop.

Importation of these crops was made according to plant quarantine regulations as described in CFR Title 7 Agriculture, 319.37 Plant Quarantine Notices of the APHIS. The prohibited genera, such as Malus, Prunus, and Pyrus, were imported under the direction of these regulations. Prohibited items were tested at the National Plant Germplasm Quarantine Center in Beltsville, Md. Restricted genera, such as Rubus and Vaccinium, were imported according to post-entry regulations, at the designated site of the permit holder in conjunction with state regulations.

\section{APPLE}

The USDA sponsored 10 expeditions to collect apples (Table 1). The countries where the expeditions took place included Armenia, China, Europe, Georgia, Japan, Kazakhstan, Korea, Kyrgyzstan, Russia, Taiwan, Tajikistan, and Uzbekistan and included more than 13 scientists. Four trips were taken solely in Kazakhstan, a center of diversity for Malus. Ancient Malus species were disseminated by birds and mammals to central Asia. Malus sieversii likely evolved in the isolated area of the Tien Shan Mountains (Robinson et al., 2001). In the four trips to Central Asia, over 130,000 seeds were collected from 900 wild apple seedlings across a very broad range (Fig. 1). M. sieversii is considered to be the main genetic component of Malus $\times$ domestica. The collection along with evaluation of seedlings from this collection is highlighted: Forsline (2006); Forsline et al. (2004); Hokanson et al. (1997); Luby et al. (2001); and Pons (2006). Evaluation of the material for disease resistance is an ongoing project with the Plant Pathology Department at Cornell University (Forsline and Aldwinckle, 2004). Allelic diversity in the core $M$. sieversii collection was maximized through selection among both seedcollected and clonally collected material. Controlled pollinations were used to maximize retention of these alleles in seed for long-term conservation (Volk et al., 2005).

Collection of seven Malus species from Sichuan China was completed in 1997. Malus orientalis, another species closely related to Malus $\times$ domestica, was collected in the Russian Caucasus and in Turkey in 1998 and 1999. Additional collections of this species were made in conjunction with explorations for other fruit species in Armenia and Georgia in 2002 and 2004.

\section{GRAPE}

Grapes were collected in Pakistan, Kazakhstan, and Mexico. In Pakistan, a superior clone of native Vitis jacquemontii with resistance to powdery mildew, incited by the fungus Uncinula necator, was obtained for use in humid climates. The cultivar $V$. vinifera 'Boyalsing', collected in Pakistan in 1988, is being tested in Napa, Calif., for potential as a wine grape. Four wild grape species were collected in Mexico. 
Table 1. Fruit exploration trips between 1980 and 2004, sponsored by the USDA Agricultural Research Service, Plant Exchange Office.

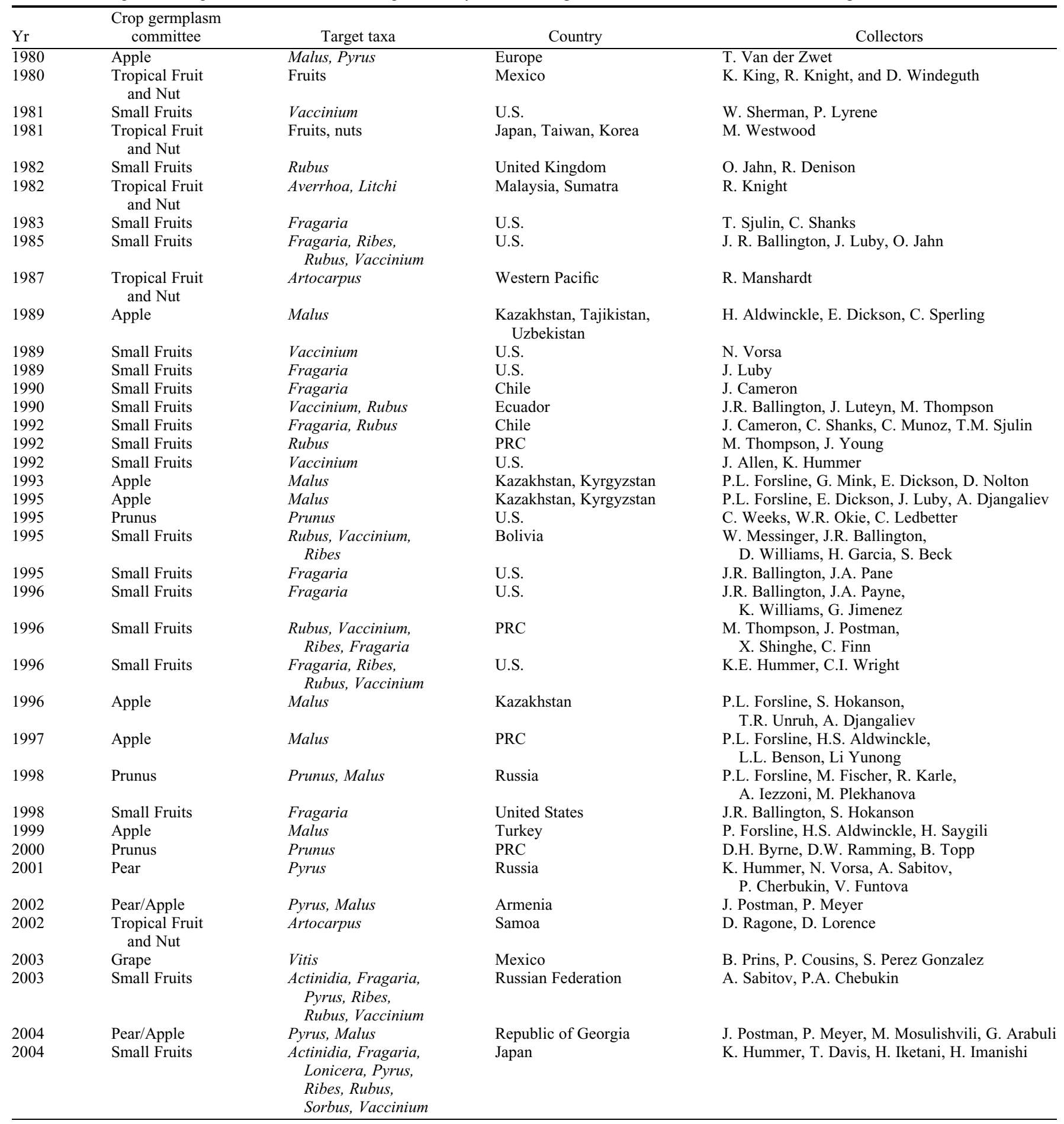

\section{STONE FRUIT}

Five expeditions collected stone fruit germplasm in China Japan, Kazakhstan, Russia, and the United States. Peach (Prunus persica) was collected from China. Fruit of high quality and uniform shape were observed. Fruit with low ethylene production were collected. The doughnut peach with white flesh ('Pen Tao') was also collected. The expedition to Russia included visits to the national cherry collections at the VIR stations in St. Petersburg, Orel, Michurinsk, and Krymsk. Among the valuable germplasm obtained were cherry rootstocks and sour cherry (Prunus cerasus) germplasm. Accessions with genetic resistance to cherry leaf spot disease were also identified and collected. Some of this germplasm may prove valuable for direct use, while other material will be used in crop improvement.

\section{PEAR}

Pears were collected from selected locations in Eastern Europe including the former Yugoslavia, Armenia, Georgia, Kazakhstan, and Siberian Russia. One hundred forty-three
Pyrus communis L. accessions obtained in Eastern Europe have been evaluated for resistance to pear psylla (Cacopsylla pyricola (Foerster) (Homoptera: Psyllidae). PI 617614 and PI 617615-notable for their resistance (Bell, 1992)- have been incorporated into the U.S. pear breeding program.

\section{SMALL FRUIT AND TEMPERATE SPECIALTY CROPS}

Nineteen USDA-sponsored foreign and domestic expeditions were targeted to collect temperate berry and specialty crops between 


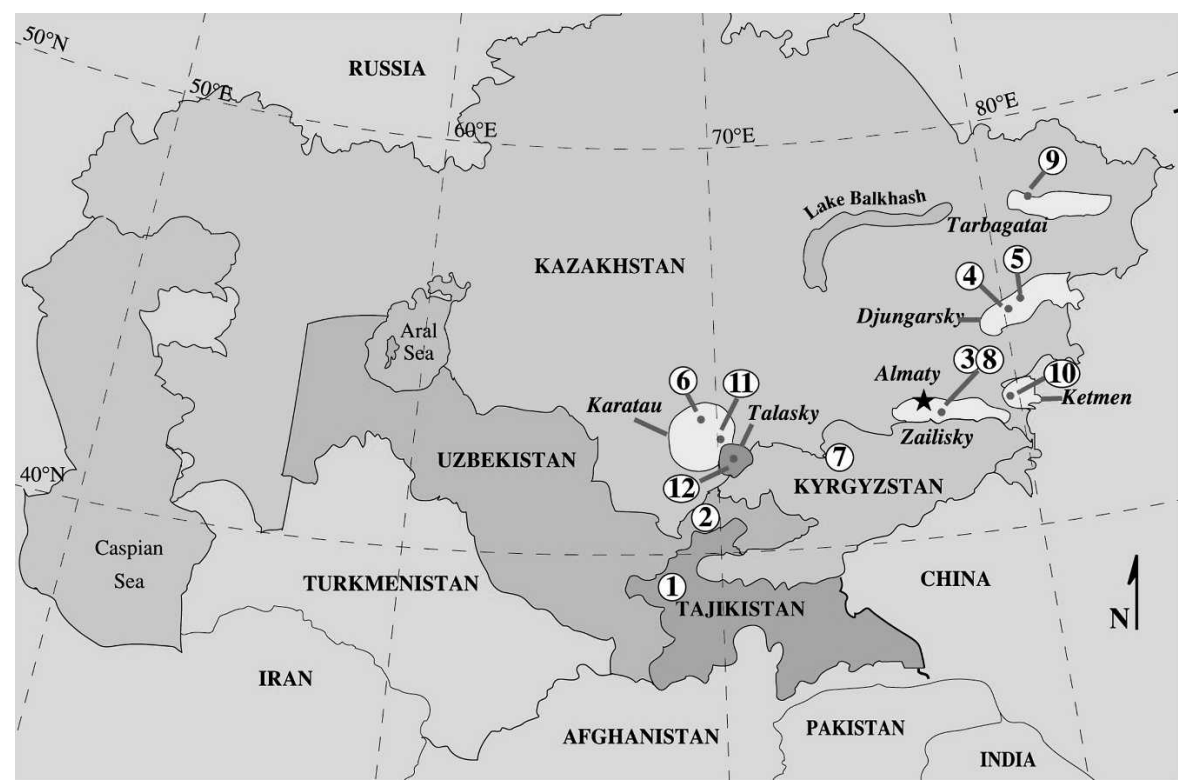

Fig. 1. Map of the 12 regions in Central Asia where M. sieversii (Lebed.) was collected in 1989, 1993, 1995, and 1996.

1980 and 2004. Expeditions to gather strawberries (Fragaria) genetic resources were taken in Chile, China, Japan, and Russia (Hummer et al., 2003; Sabitov, Hummer and Davis, 2005) as well as within the United States. This significantly expanded the material resistant to root and foliar diseases. Wild material from Asia will be useful in determining phylogenic relationships among species and in investigating the origin of the North American octoploid genome.

The highly diverse genus Rubus was collected on 10 expeditions including to Bolivia, Chile, Ecuador, China, Japan, Russia, the United Kingdom, and the United States. More than 500 accessions were collected on these trips. Representatives of most of these new species have begun to be incorporated into raspberry, blackberry, and hybrid berry breeding programs throughout the United States and internationally. These newly collected species could broaden the genepool to improve low chilling, pest and disease resistance, drought, heat, and cold tolerance, improved yielding, and improved fruit quality of cultivars in the coming years.

Vaccinium, the genus that includes blueberry (Vaccinium section Cyanococcus), cranberry $(V$. oxycoccos $)$ and lingonberry ( V. vitis-idaea), was collected in 12 expeditions, in Bolivia, Ecuador, Chile, China, Georgia, Japan, Russia, and the United States. In South America and in Asia, the native peoples gather Vaccinium fruits from wild stands for juice and preserves. The native heritage and folklore in each of these areas support the healthful and nutritive properties of the consumption of these fruits. Recent laboratory tests have confirmed the high levels of antioxidant components in these fruits.

\section{TROPICAL FRUIT AND NUT}

Tropical fruit and nut species were collected in 6 trips to Samoa, West Pacific
Islands, Malaysia, Sumatra, Mexico, Japan, and Taiwan. More than 115 accessions have been established in tropical gardens and at the Hilo Repository in Hawaii. Breadfruit (Arctocarpus), starfruit (Averrhoa), lychee (Lichi), avocado (Persea), and other tropical fruit and nut genera were collected.

\section{DISCUSSION AND CONCLUSION}

More than 3000 accessions have been introduced as a result of these USDAsponsored fruit, nut, and specialty crop expeditions. Fruit breeders across the United States and throughout the world have had new availability to diverse genetic resources to overcome bottlenecks and widen genetic diversity for crop improvement. These newly collected low chilling Rubus species have been crossed to incorporate new genes into genetic enhancement activities. New hybrids are now available for improving raspberries, blackberries, and hybrids to survive warmer climates. In apples, new sources of genes for resistance to major diseases are in use by breeders throughout the world.

Over the past 25 years, there have been changes in procedures and protocols for collection as a result of the Convention on Biological Diversity (1993), and the International Treaty on Plant Genetic Resource for Food and Agriculture (2004). In the 1980 s, countries, such as China, opened and permitted plant collecting for fruits. Since the late 1990s, however, this accessibility has been denied to USDA-sponsored plant expeditions (Fig. 2). Plant exploration continues where countries can prepare bilateral agreements and allow such exchanges to be made. The ebb and flow of political overtones concerning the accessibility of genetic resources will dictate where plant expeditions will occur in the future. The United States continues to operate with the

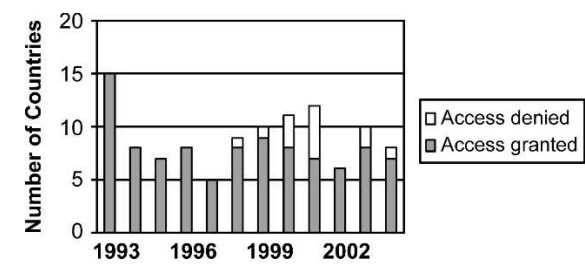

Fig. 2. Country accessibility for plant exploration by the USDA Agricultural Research Service, National Plant Germplasm System, between 1993 and 2004.

mandate to freely distribute plant genetic resources internationally for research purposes and to encourage the development of genetic resources in to improved crops around the world.

\section{Literature Cited}

Bell, R. 1992. Additional East European Pyrus germplasm with resistance to pear psylla nymphal feeding. HortScience 27: 412-413.

Brooks, H.J. and D.W. Barton. 1977. A plan for national fruit and nut germplasm repositories. HortScience 12:298-300.

Forsline, P.L., H.S. Aldwinckle, E.E. Dickson, J.J. Luby, and S.C. Hokanson. 2004. Collection, maintenance, characterization and utilization of wild apples of Central Asia, p. 1-61. In: J. Janick, P. Forsline, E. Dickson, R. Way, and M. Thompson (eds.). Horticultural Reviews, Vol. 29. Wild apple and fruit trees of Central Asia. Wiley, New York.

Forsline, P.L. and H.S. Aldwinckle. 2004. Evaluation of Malus sieversii seedling populations for disease resistance and horticultural traits. Acta Hort. 663:529-534

Forsline, P.L. 2006. 'Forum'-Travels to gather, improve apples start to bear fruit. Agr. Res. 54:2

Hokanson, S.C., J.R. McFerson, P.L. Forsline, W.F. Lamboy, J.J. Luby, A.D. Djangaliev, and H.S. Aldwinckle. 1997. Collecting and managing wild Malus germplasm in its center of diversity. HortScience 32: 173-176.

Hummer, K.E., N. Vorsa, A. Sabitov, P. Cherbukin, and V. Funtova. 2003. Collecting temperate fruits and nuts in the Siberian Far East of Russia. Plant Genet. Resources Nwsl. 134:13-17.

Luby, J., P.L. Forsline, H.S. Aldwinckle, V. Bus, and M. Geibel. 2001. Silk Road applescollection, evaluation, and utilization of Malus sieversii from Central Asia. HortScience $36: 225-231$

Pons, L. 2006. Remarkable Kazak apples. Agr. Res. 54(1):4-6.

Robinson, J.P., S.A. Harris, and B.E. Juniper. 2001. Taxonomy of the genus Malus Mill (Rosaceae) with emphasis on the cultivated apple, Malus domestica Borkh. Plant Syst. Evol. 226:35-58.

Sabitov, A., K. Hummer, and T. Davis. 2005. Iturup and Sakhalin Island strawberries. HortScience 40(4):1127. (abstr.).

Volk, G.M., A.A. Reilley, A.D. Henk, C.M. Richards, P.L. Forsline, and H.S. Aldwinckle. 2005. Ex situ conservation of vegetatively propagated species: development of a seedbased core collection or Malus sieversii. J. Amer. Soc. Hort. Sci. 130:203-210. 